\title{
HONEYBEE VIRUSES PRESENCE IN SERBIAN APIARIES: A REVIEW
}

\author{
Tamaš Petrovićc ${ }^{*}$, Dejan Vidanović ${ }^{2}$, Diana Lupulović ${ }^{1}$, \\ Gospava Lazić ${ }^{1}$, Sava Lazić ${ }^{1}$
}

${ }^{1}$ Scientific Veterinary Institute "Novi Sad", Novi Sad, Republic of Serbia

${ }^{2}$ Veterinary Specialized Institute "Kraljevo", Kraljevo, Republic of Serbia

\section{Abstract}

The honey bee Apis mellifera is an important beneficial insect recognized by production of honeybee products, having an important role in agricultural production as a pollinator, and playing an equally crucial role in conserving the biodiversity in many natural ecosystems. According to available literature data, during the period of more than 30 years, dramatic losses of honey bee winter colonies have frequently been reported all over the world, which could have a direct influence on human food resources and can affect not only apiculture or agriculture, but also pose an anthropological threat. One among many reasons for global bees-decline phenomenon is the influence of many viruses on honeybees' health. Until today, at least 24, and even more viruses were detected in honeybees, and for many of them the pathogenicity and impact on honeybees' health still remain unknown. However, it is well known that some of these viruses like acute bee paralysis virus, chronic bee paralysis virus, deformed wing virus, black queen cell virus, sacbrood virus, Kashmir bee virus, Israeli acute paralysis virus, slow bee paralysis virus, Varroa destructor virus-1 and some others have direct or indirect influence on individual honeybee or on whole honeybees' colony health. In this paper, an overview of existing literature data on the presence, prevalence and characterization of honeybee viruses detected in honeybee colonies and apiaries from different regions in Serbia from first detection of their presence in 1986 till nowadays is presented and discussed.

Key words: honeybees, virus presence and prevalence, Serbia

${ }^{1 *}$ Corresponding Author: tomy@niv.ns.ac.rs 


\title{
PREGLED PRISUSTVA VIRUSA PČELA U PČELINJACIMA U SRBIJI
}

\author{
Tamaš Petrović ${ }^{1}$, Dejan Vidanović ${ }^{2}$ Diana Lupulović ${ }^{1}$, \\ Gospava Lazićn ${ }^{\text {, Sava Lazić }}{ }^{1}$
}

${ }^{1}$ Naučni institut za veterinarstvo „Novi Sad“, Novi Sad, Republika Srbija
${ }^{2}$ Veterinarski specijalistički institut “Kraljevo”, Kraljevo, Republika Srbija

\section{Kratak sadržaj}

Medonosna pčela Apis mellifera je važan korisni insekt, prepoznat po proizvodnji pčelinjih proizvoda, koji ima važnu ulogu u poljoprivrednoj proizvodnji kroz oprašivanje, a igra podjednako ključnu ulogu i u očuvanju biodiverziteta u mnogim prirodnim ekosistemima. Prema dostupnim literaturnim podacima, u poslednjih više od 30 godina, širom sveta se često prijavljuju dramatični gubici pčelinjih društva nakon prezimljavanja, što može direktno uticati na resurse hrane za čoveka i može uticati ne samo na pčelarstvo ili poljoprivredu, već ima i antropološke pretnje. Jedan od mnogih razloga za globalni fenomen opadanja broja pčela je uticaj mnogih virusa na zdravlje pčela. Do danas je kod pčela otkriveno 24, pa i više vrsta virusa, a za mnoge od njih još uvek nije poznata patogenost po zdravlje pčela. Međutim, dobro je poznato da neki od ovih virusa, poput virusa akutne paralize pčela, virusa hronične paralize pčela, virusa deformisanih krila, virusa crnog matičnjaka, virusa mešinastog legla, Kašmirskog virusa pčela, virusa izraelske akutne paralize pčela, virusa spore paralize pčela, Varroe destructor virusa-1 i neki drugi, imaju direktan ili indirektan uticaj na zdravlje pčele kao individue ili na zdravlje cele pčelinje zajednice. U ovom radu je dat i razmotren pregled postojećih literaturnih podataka o prisustvu, rasprostranjenosti i karakterizaciji virusa medonosnih pčela otkrivenih u pčelinjim društvima i pčelinjacima iz različitih regiona Srbije od prvog otkrivanja njihovog prisustva u Srbiji 1986. godine do danas.

Ključne reči: medonosna pčela, prisustvo i prevalenca virusa, Srbija

\section{INTRODUCTION}

The western honey bee Apis mellifera is an important beneficial insect recognized by production of honeybee products, which plays an essential role in 
the ecology of natural environments and in agricultural production through pollination (Petrović et al., 2013; Ćirković et al., 2018; Chapman et al., 2019). Almost one-third of distinctive agricultural crops need bees' pollination (O'Neal et al., 2018). Pollination services are mandatory for the production of crops like fruits, nuts and fibres, but also the production of many other agricultural crops is significantly improved by pollination (Tantillo et al., 2015). Also, honeybees play an equally crucial role in conserving the biodiversity in many natural ecosystems. The value of bee pollination services is commonly measured in billions of dollars representing about $9.5 \%$ of the value of crops across the world (Tantillo et al., 2015). In United States, the value of honeybee pollination for agriculture has been estimated at more than 14.6 billion dollars (Morse and Calderone, 2000). According to FAO and the European Union, the value of pollination is 20 - 30 times higher than the value of honey production (Antúnez et al., 2012).

According to available literature data, in the last 30 years, dramatic honey bee winter colony losses have been reported frequently from different regions all over the world (Breeze et al., 2014). Pollinating insect declines have a direct influence on human food resources and can affect not only apiculture or agriculture but also has anthropological threats (Francis et al., 2013; McMenamin and Flenniken, 2018). Among reasons for global bees-decline phenomenon several factors could be appointed like pesticides, destruction of habitat, modern industries, intensive agriculture, parasites/pathogens, climate change, and inadequate food supply (Ullah et al., 2021). The honeybees' health is often compromised by different pathogens, such as the mites Varroa destructor and Acarapis woodi, the microsporidia Nosema ceranae and Nosema apis, the bacteria Paenibacillus larvae and Melissococcus plutonius and different viruses (Antúnez et al., 2012). Many researchers demonstrated that viral infections in honey bee colonies are considered a key risk for their health at both individual and colony level (Tantillo et al., 2015; Levin et al., 2019; Beaurepaire et al., 2020; Ullah et al., 2021).

Viruses are mostly the hidden enemies of honey bees as compared to other pathogens, because most of infections pass without clinical manifestation or characteristic disease signs (Ullah et al., 2021). During the last two decades, honeybee virus infections have been increasingly investigated and have emerged as one of several causes of the honeybee colony losses (Tantillo et al., 2015). However, viruses are probably the least understood part of honeybee pathology mainly because of the lack of information of the objective data about viral disease outbreaks (Toplak et al., 2012). During the last few years, our understanding of the diversity of viruses infecting bee species has grown dramatically, especially due to rapid improvements and increasing accessibil- 
ity of next-generation sequencing approaches. So far, honey bees have been reported to be the host to at least 24 and even more (Beaurepaire et al., 2020) viruses, primarily positive-strand RNA viruses belonging to order Picornavirales, and in the families Dicistroviridae and Iflaviridae. These ones are able to infect the different developing stages of the honeybees, including eggs, larvae, pupae and adults (Allen and Ball, 1996; Tantillo et al., 2015; Ullah et al., 2021). Most of them cause unapparent infections without clinical signs but in certain cases may cause serious or lethal diseases (Allen and Ball, 1996; Antúnez et al., 2012; Tantillo et al., 2015; Ullah et al., 2021). Of those viruses infecting honeybees, nine viruses are considered the most common ones that are able to cause severe disease. Those viruses include acute bee paralysis virus (ABPV), black queen cell virus (BQCV), Kashmir bee virus (KBV) and Israeli acute paralysis virus (IAPV) from the family Dicistroviridae, deformed wing virus (DWV), sacbrood virus (SBV), slow bee paralysis virus (SBPV), and Varroa destructor virus-1 (VDV1, or DWV-B) from the family Iflaviridae, and chronic bee paralysis virus (CBPV) as taxonomically unsystematic virus (Chen and Siede, 2007; de Miranda et al., 2010; de Miranda and Genersch, 2010; Antúnez et al., 2012; Toplak et al., 2012; Petrović et al., 2013; Chagas et al., 2019, Ullah et al., 2021). In addition, from 2015 to 2018, sequencing studies identified sequences corresponding to positive single-stranded RNA viruses from several other families and genera including Tymoviridae, Secoviridae, Nodaviridae, and Flaviviridae families; the Sobemovirus and Negevirus genera; the new genus Halictivirus; and a Nora-like virus; then negative single-stranded RNA viruses from the families Bunyaviridae and Orthomyxoviridae; also viruses from the family Rhabdoviridae, double-stranded RNA viruses from families Partitiviridae and Totiviridae as well as double-stranded DNA viruses (Apis mellifera filamentous virus and Osmida cornuta nudivirus), and single-stranded DNA viruses from Circoviridae and Parvoviridae families (Grozinger and Flenniken, 2019). Many of these viruses are also found in plants and fungi, and further studies will be needed to describe the role of many newly detected viruses and their potential influence on bees' health.

Often, clinically visible symptoms of honey bee virus diseases are mostly associated with other infectious agents, such as the presence of microsporidia Nosema apis and strong infestations with Varroa destructor mites (Ullah et al., 2021). Several studies implicate that the combination of certain virus infections and Varroa destructor infestation represent a serious threat to honeybee health (Allen and Ball, 1996; Chen et al., 2004; de Miranda et al., 2010; Antúnez et al., 2012; Tantillo et al., 2015; Ullah et al., 2021). An established opinion among researchers is that Varroa in association with a range of hon- 
eybee viruses is a significant factor in the losses of managed honeybee colonies seen globally. The spread of this mite to the Western honeybee - Apis mellifera, and its ability to act as a viral reservoir, incubator, activator and transmitter has resulted in levels of certain viruses that affect the survival of the colony (Tantillo et al., 2015).

Viruses spread in honeybees by two ways: vertical and horizontal transmission (de Miranda et al., 2012; Chagas et al., 2019; Beaurepaire et al., 2020). In vertical transmission route, viruses could spread from the infected queen by trans-ovarial transmission, through drones by trans-spermal transmission, or during their mating - known as venereal transmission to the offspring. In horizontal transmission route, the viruses spread amongst colony members of same age generation and between same and different hives or apiaries via oral or contact route (de Miranda et al., 2012, Chagas et al., 2019; Ullah et al., 2021). In addition to this direct transmission routes, some viruses, like DWV, mainly spread among honeybees via Varroa destructor mites that become infected from infected bees and behave as a carrier to spread viruses to healthy bees when they feed on them (vector-borne transmission) that represents an example of indirect transmission (Ullah et al., 2021).

In nature, $\mathrm{BQCV}, \mathrm{DWV}, \mathrm{KBV}$, and SBV infect larvae and pupae as well as adult bees, while ABPV affects only adult bees (Chen et al., 2004). The first detected honeybee virus was SBV detected at the beginning of 20th century (1913) in USA (White, 1913), much earlier than many of human and other animal viruses. SBV affects larvae of honeybees and causes sacbrood disease. Affected larvae change from pearly white to grey and finally black. When affected larvae are carefully removed from their cells, they appear to be a sac filled with water. The adult bees develop a latent infection characterized only by a decreased life span, without acclaimed symptoms (Berènyi et al., 2006). This latent infection is very important for the transmission of SBV since virus is accumulated in the head and in the hypopharyngeal glands of infected nurse bees that are responsible for feeding the larvae (Tantillo et al., 2015). Also, a positive correlation was observed between the intensity of $V$. destructor prevalence and the presence of SBV in adult bee samples (Tentcheva et al., 2004). The frequencies of SBV infection were much higher during the spring period, when the brood season begins and large numbers of susceptible larvae and young adults are present (Berènyi et al., 2006)

$\mathrm{BQCV}$ was first detected in brown and black coloured queen larvae and prepupae but it also affects larvae and pupae of worker bees without causing signs (Antúnez et al., 2012). In honeybee colonies, BQCV is more prevalent in adult bees than in the pupae, although it clinically affects mainly developing queen larvae and pupae of the queen, representing the primary hosts of 
the virus. These larvae acquire a pale yellow appearance and the symptoms are similar to those caused by SBV infection (Tentcheva et al., 2004; Tantillo et al., 2015). An important correlation was observed between the incidence of BQCV and Nosema apis in honeybee colonies with a peak of infection and infestation during spring and early summer (Allen and Ball, 1996; Tantillo et al., 2015).

DWV was first isolated in Japanese apiaries from adult honeybees with a particular deformity of wings (Bailey and Ball, 1991), and is one of the most widely distributed honeybee viruses around the globe (Tantillo et al., 2015). The presence and high prevalence of DWV is reported in all continents except in Oceania (Allen and Ball, 1996). DWV has been detected in more than 20 bee species, and there is evidence that it replicates in several of these species and causes damaging symptoms in two bumble bee species (i.e., Bombus terrestris and Bombus pascuorum), as well as in A. mellifera (Grozinger and Flenniken, 2019). Infection with DWV is typically associated with the presence of $V$. destructor, and results in wings deformation in honeybees. Also, it is one of the most studied viruses that affect honeybees due to its relation with colony losses induced by honeybee's mite V. destructor (Antúnez et al., 2012). There are several routes of DWV transmission that can influence its abundance and virulence. In bee colonies, DWV is transmitted vertically from queen or drone to the offspring, and horizontally via trophallaxis and shared food resources, but very often by Varroa destructor as their biological vector (Grozinger and Flenniken, 2019). DWV is able to infect all bee developmental stages from eggs to adults, even if it shows a higher replication in pupae. DWV is a virus with a low pathogenicity and is often responsible for latent infections that can appear in clinical form after a stressful situation such as high infestation with Varroa destructor and some others (Tantillo et al., 2015). DWV levels in bees parasitized by Varroa are significantly higher than levels of bees infected by other routes. Also, Varroa appear to benefit from this interaction because they produce more offspring while feeding on DWV-infected pupae (Grozinger and Flenniken, 2019)

CBPV was first isolated in 1963 from diseased honeybees (Bailey et al., 1963 ) and it is present at all continents. This virus can persist throughout the years as a subclinical infection, and the prevalence of the infection did not follow any seasonal pattern (Tentcheva et al., 2004; Tantillo et al., 2015). At low levels, infected colonies do not show clinical signs, but high level of those viruses induces high mortality rates. CBPV induces abnormal trembling of the wings and body of honeybees and sometimes black individuals crawling at the hive entrance can be detected. These are the main two clinical symptoms in bees infected with CBPV. The wings are partially spread or dislocated. In some 
cases, the crawling bees can be in large numbers representing the clinically evident disease (Antúnez et al., 2012). CBPV was detected in queens and all their offspring at all developmental stages including eggs. Crowded condition of the colonies promotes the spread of the virus by direct contact of healthy bees with paralysed individuals, but vertical virus transmission is also possible. Interestingly, CBPV infections have never been related to Varroa destructor infestations and the virus has not been reported (Tantillo et al., 2015).

$\mathrm{ABPV}$ is a common infective agent of honeybees, frequently detected in apparently healthy colonies (Allen and Ball, 1996; Bakonyi et al., 2002; Tentcheva et al., 2004; Berényi et al., 2006). Clinical form of infection is sometimes activated and exacerbated by stressful environmental factors such as Varroa mite infestations, bacterial infections, presence of insecticides or some other stress factors. In addition, ABPV has been indicated as one of the major factors contributing to the mortality of honeybees infested with $V$. destructor and it was detected to be a primary cause of mortality in weakened colonies from many countries like ex-Yugoslavia, Germany, France, Hungary and USA (Bakonyi et al., 2002; Tantillo et al., 2015). Clinically evident infection of ABPV is characterized by rapidly progressing paralysis, including trembling, inability to fly and the gradual darkening and loss of hair from the thorax and abdomen, and rapid death of adults. ABPV could attack all life cycle stages of honeybees, but the pupae are the most favourable hosts for virus multiplication (Chen et al., 2004; de Miranda et al., 2012; Tantillo et al., 2015). ABPV could enter the colony by foodborne and venereal transmission; however Varroa destructor plays a crucial role in spreading of this virus both as a vector and as an activator of viral infection (Tantillo et al., 2015).

IAPV was first isolated in 2004 from Israeli apiaries, where it caused a significant mortality in honeybees (Tantillo et al., 2015). The virus was found to be present in every developmental stage of honey bee and its infection was observed almost in all tissues, but mostly existed in hypopharyngeal glands, alimentary canal and nervous system (de Miranda et al., 2012). IBPV is closely related to KBV and ABPV. Besides Israel, IBPV is widespread in Australia and USA. Like ABPV and many other bee viruses, IBPV usually persists in bee colonies at low titres without clinical symptoms. However, different stress factors influencing the weakening of the honeybee defences can exacerbated the IBPV infection that leads to death of the honeybees. Clinical symptoms of such infection are very similar to the ABPV infection with rapidly progressing paralysis, including trembling, inability to fly, gradual darkening and loss of hair of the thorax and abdomen resulting in massive deaths of adult bees (Tantillo et al., 2015). 
KBV is endemically present in Australia and in the USA, and has been reported in Europe only rarely (Tentcheva et al., 2004; Berènyi et al., 2006). Like IBPV and ABPV, KBV persists at low titres in apparently healthy colonies until different stress factors activate the viral multiplication causing the clinical manifestation of disease and death of the colony. Different developing stages of bees could be hit by infection, but without clearly defined disease symptoms. The transmission of KBV in naturally infected colonies can occur via multiple routes including foodborne transmission, but also transmission by Varroa destructor as physical or true vector of this virus. Recently, KBV was proved to be highly important marker of Colony Collapse Disorder (CCD), i.e., rapid loss of the colony's adult bee population (Tantillo et al., 2015).

Slow bee paralysis virus (SBPV) primarily affects the forelegs (paralyses) of honey bees but can also be found in the head, salivary gland, mandibular and hypopharyngeal glands, crop, fat body, while present in the thorax, midgut, hindlegs and rectum in low quantity. It was correlated with colony collapse in England, but it is mostly less prevalent in other European apiaries (de Miranda et al., 2012).

The diagnosis of bee virus infections is difficult because honey bee viruses usually persist as unapparent infections and cause no clinical signs of disease, and because the fact that bee colonies can be simultaneously attacked by more than one virus as well as other pathogens. Multiple viral infections in bees have been reported by a number of authors (Anderson and Gibbs, 1988; Chen et al., 2004; Toplak et al., 2012; Petrović et al., 2013; Simeunović et al., 2014; Ćirković et al, 2018).

The increased losses of bee colonies have been also reported in Serbia during the last two decades. Because of the effects of viral infections on honeybee health and honeybee colonies losses, the aim of our study was to assess the presence and distribution of different honeybee viruses in Serbian apiaries. In this paper, the authors presented an overview of existing literature data on the presence, prevalence and characterization of honeybee viruses detected in honeybee colonies and apiaries from different regions in Serbia, from the first detection of their presence in 1986 till nowadays.

\section{THE PRESENCE OF HONEY BEE VIRUSES IN SERBIAN APIARIES}

By reviewing the available literature data only limited number of studies on investigating the presence of viruses in Serbian honeybee colonies and apiaries were found. The first detection of viruses in Serbian apiaries has been done by Kulinčević and co-workers even 35 years ago (Kulinčević et al., 1990). 
In that study, samples of adult honeybees were collected from 2 apiaries near Belgrade in autumn 1986 and early spring 1987, and tested on virus presence by electron microscope and immunodiffusion test (with different bee virus antisera). The results of the study confirmed the presence of 4 bee viruses, being: ABPV, Cloudy Wing Virus (CWV), DWV (at that time known as J strain of Egypt bee virus) and BQCV in Serbian apiaries.

After a long time period without any published data on the presence of honey bee viruses in Serbia, the first surveillance study on viruses presence based on molecular diagnostic methods was done in apiaries in two districts in Vojvodina Province, northern part of Serbia (Petrović et al., 2013). In this study, 30 bee samples originating from 15 apiaries at 13 locations in districts of South Bačka (7) and Srem (6) in Serbia, sampled from June 2011 to May 2013, were tested for the presence of six honeybee viruses: ABPV, BQCV, CBPV, DWV, KBV and SBV. The sampled bee colonies were of different health status ranging from apparently clinically normal colonies to ill or dead bees associated with abnormal mortally or sudden colony losses. By using one-step reverse transcription-PCR (RT-PCR) method, the presence of bee virus was detected in all examined samples (100\%). The most prevalent virus was BQCV, present in all $30(100 \%)$ samples, followed by SBV, DWV, CBPV and ABPV detected in 21 (70\%), 20 (67\%), 18 (60\%) and 17 (57\%) samples, respectively. KBV was not detected in any of samples. Petrović et al. (2013) pointed on the difference between the obtained data in regard to the location (district) of the tested apiaries. Among 20 analysed honeybee samples from 9 apiaries at 7 locations in South Bačka District all 20 (100\%) samples were positive on the presence of BQCV, 17 (85\%) on the presence of CBPV, $16(80 \%)$ on the presence of SBV, $11(55 \%)$ on the presence of DWV and $10(50 \%)$ samples on the presence of ABPV. The results on virus presence in 10 bee samples from 6 apiaries and 6 locations on the territory of Srem District were slightly different. The most prevalent viruses were BQCV in 100\% (10/10) and DWV in 90\% (9/10) tested samples, followed by ABPV found in 70\% (7/10), SBV found in 40\% (4/10) and CBPV found in only 1 out of 10 (10\%) examined samples. Besides BQCV, the most prevalent bee virus found in South Bačka District was CBPV and in Srem District it was DWV. The authors also pointed out that this difference could not be seen in clinical manifestation of the disease on the field. The lack of differences in clinical manifestations might be attributed to the relatively small number of examined samples or insufficient anamnestic data obtained from the field. If such differences really exist and remained unnoticed, it might be influenced by some factors that were not identified at that time. Further on, the data obtained in this study showed that in most of the tested samples $(96.67 \%)$, 
more than one virus was identified. Only one analysed sample (3.4\%) was infected with only one virus, 2 (6.7\%) with two viruses, 14 (46.7\%) with three viruses, 6 (20\%) with four viruses, and 7 (23.3\%) samples were found positive on five viruses simultaneously. Almost the half of the analysed samples had 3 , and more than $40 \%$ of the analysed samples had 4 or 5 simultaneous viral infections. The severity of clinical manifestations with high bee losses was associated with higher amount of viruses detected in the samples (Petrović et al., 2013). The results obtained in this study indicated high prevalence of 5 out of 6 examined bee viruses in Serbian apiaries, and the great burden of surveyed apiaries caused by simultaneous and multiple viral infections corresponds with the data reported from other countries (Chen et al., 2004; Tentcheva et al., 2004; Berènyi et al., 2006; Antúnez et al., 2012; Toplak et al., 2012).

Simeunović et al. (2014) tested the presence of bee viruses DWV and ABPV by real-time RT-PCR method in 55 seemingly healthy colonies located at 11 apiaries ( 5 colonies per apiary) distributed in northern, southern, eastern, western and central part of the Republic of Serbia. The results revealed the presence of DWV at each sampling location - tested apiary, and ABPV in 10 out of 11 apiaries. Among the analysed samples, DWV was detected in $76.4 \%$ and ABPV in $61.8 \%$ of tested samples. From the geographic point of view, the highest frequency of DWV and ABPV (both viruses were found in $100 \%$ of samples) was established in the northern region of Serbia (Vojvodina Province) with sampling locations in Odžaci and Bačka Palanka as well as locations Valjevo (Western Serbia) and Kladovo (Eastern Serbia). Contrary to these findings, $\mathrm{ABPV}$ was not detected in any of the samples from the western most sampled location (Prijepolje). Moreover, simultaneous infections with DWV and ABPV were identified in $50.9 \%$ of samples (28/55 colonies). Single infections with DWV were found in $23.6 \%$ samples (13/55 colonies) and with $\mathrm{ABPV}$ in $9.1 \%$ samples (5/55 colonies). At least one virus was detected in $85.5 \%$ samples and in $85.45 \%(47 / 55)$ colonies. Only $14.5 \%$ (8/55) of sampled colonies were negative for the presence of tested viruses (Simeunović et al., 2014). The authors concluded that high incidence of DWV and ABPV positive samples found in clinically asymptomatic colonies can be the consequence of inefficient and delayed Varroa treatment since the role of this mite in the transmission and activation of honey bee viruses is well known.

Similar, yet more extensive research was done by Ćirkovic et al. (2018), who studied the prevalence DWV, CBPV, ABPV and SBV in colonies of different strength located in five regions of Serbia. In addition, the genetic relationship between nucleotide sequences of detected bee virus strains from Serbia and those published in NCBI GenBank from different parts of the world 
was investigated. In total, 150 colonies from 32 apiaries (about 5 colonies per apiary) located in 5 administrative regions in Serbia (Vojvodina Province as Northern Serbia, Western Serbia, Central Serbia, Eastern Serbia and Southern Serbia) were sampled during autumn 2017. The sampling strategy was to sample two strong, one medium and two weak colonies from each apiary. The selected colonies were without visible clinical signs of any disease. Using a realtime RT-PCR analysis at least one virus was detected in $87.33 \%$ of tested colonies. The most prevalent virus was DWV found in $74 \%$ colonies, followed by ABPV, SBV and CBPV (identified in $49.30 \%, 24.00 \%$ and $6.70 \%$ colonies, respectively). Single virus infection was found in $28.67 \%$ colonies (DWV, ABPV, SBV and CBPV in $21.33 \%, 4.0 \%, 2.67 \%$ and $0.67 \%$ colonies, respectively). In more than a half of tested colonies (58.66\%), simultaneous infection with more than one virus was detected. In $12.67 \%$ of tested colonies, not any of examined viruses was found. With regard to the situation across the regions, DWV had the highest prevalence in all regions $(66.70-83.30 \%)$, while the least prevalent virus was CBPV $(0-19 \%)$. Except for DWV, the prevalence of the remaining three viruses differed significantly between the regions. The ABPV was highly prevalent in Vojvodina Province and in Eastern Serbia, but with a low prevalence in Central Serbia. Also, SBV was highly prevalent in Vojvodina Province and mainly low-prevalent in other regions. The highest prevalence of CBPV was detected in Southern Serbia, than in Eastern Serbia, quite low prevalence (about 5\%) was detected in Central and Western Serbia, and the virus was not detected in apiaries from Vojvodina Province. No significant differences were found in the prevalence of DWV, ABPV, SBV and CBPV infections between weak, medium and strong colonies (Ćirković et al., 2018). For genetic relationship and phylogenetic analysis partial coding sequences encoding a part of polyprotein gene of DWV, a capsid protein gene of ABPV, a part of RNA-dependent RNA polymerase (RdRp) gene of CBPV, and a part of polyprotein gene of SBV of detected virus strains in Serbia were used along with related sequences deposited in NCBI GenBank. The similarities found for $9 \mathrm{DWV}$ strains from Serbia with deposited nucleotide sequences in NCBI GenBank were 99 to $98 \%$. Some of the nucleotide sequences of Serbian DWV strains were highly similar to those from United Kingdom, but most of them were similar to virus strains from different countries, which is in line with the hypothesis of relatively recent evolutionary diversification of DWV and its worldwide distribution. The similarity between nucleotide sequence of ABPV strain from Serbia and those deposited in NCBI GenBank was between 93 and 97\%. The Serbian ABPV strain was distant from those from north and western European countries, and the highest similarity was found with Hungarian 
ABPV strains. This may be explained by the geographical vicinity and trade between beekeepers of the two countries. The Serbian SBV strains were mostly similar to those from different European countries and Russia, and more distinct from strains from other parts of the world. The similarity between nucleotide sequence of Serbian CBPV strain and other deposited in NCBI GenBank was only from 93 to $96 \%$ indicating probable distinct virus evolution in different geographic areas and the need for more studies that should be done to obtain clearer picture (Ćirković et al., 2018)

Milićević et al. (2018) tested 30 honey samples from Serbian apiaries originating from the local markets sampled from 12 different districts in central and northern Serbia, as well as 40 samples of both honeys and live and dead bees, from four apiaries without any visible health disorder, located in central Serbia. The samples were tested for the presence of BQCV, KBV, DWV, ABPV, SBV, and CBPV by multiplex RT-PCR. Out of all six examined viruses, only BQCV genome was found in 24 honey samples (80\%) from the local markets. Also, BQCV was the only virus found both in bees and honey samples from tested apiaries. The virus was detected in three out of four apiaries, and the virus prevalence at a hive level was between 86.6 and $100 \%$. The partial polyprotein coding region of detected BQCV strains were sequenced. The phylogenetic analysis showed that Serbian BQCV strains were similar to each other (98.5\%), and mostly similar to some other European strains (86.4\%) clustered by geographical origin. The high similarity observed between Serbian and Hungarian isolates that clustered together was found to be quite expected, due to the close trading and communication between two neighbouring countries, the same or similar habitat, and pasture. The most divergent virus strains were those from the USA (Milićević et al., 2018).

The testing of bees samples taken from diseased or dead honey bee colonies provided by beekeepers all over the Republic of Serbia to the Department of Biology, Faculty of Veterinary Medicine, on the presence of viruses in the five-year period (2014 - 2018) showed that the prevalence was between 73.12 and $87.16 \%$ for DWV, 61.54 and $81.45 \%$ for ABPV and between 58.82 and $64.22 \%$ for CBPV, depending of the year of testing (Stanimirović et al, 2019).

In addition to previously described studies, Tarić et al. (2019) investigated the differences between the presence of virus infections of the brood and adult bees depending of the used apiculture technology (conventional vs. traditional). There are certain regions in the Republic of Serbia where bees are still kept in a traditional way, in primitive hives made of wicker - so-called trmka hives. The study was conducted on the Pešter Plateau (1,059 km2), Raška District, southwest Serbia. Samples of bees from 144 asymptomatic honey bee colonies (120 kept in commercial hives and 24 colonies kept in traditional trmka 
hives) originating from 18 apiaries ( 15 commercial apiaries and 3 apiaries with trmka hives) were tested for the presence of the ABPV, CBPV, DWV and SBV by molecular diagnostic methods. The SBV was detected in $96.67 \%$ samples from commercial colonies and in only $33.33 \%$ samples from traditional hives. In addition, the occurrence of viruses in adult bees was significantly higher in commercial colonies. The ABPV was found in $96.67 \%$, and CBPV and DWV were detected in $100 \%$ of bee colonies for commercial purpose, contrary to the $33.33 \%$ colonies detected positive for ABPV, CBPV and DWV in traditional apiaries. Only one out of three apiaries with traditional hives was found positive for one or more viruses. The obtained data showed that in the brood and adult bees without clinical symptoms reared in a traditional way in primitive hives, the prevalence of all monitored viruses was up to $33.33 \%$, which is within the limits of normal distribution of viruses in bee colonies in natural conditions. Moreover, traditional trmka hives provide significantly better conditions for maintenance of bee health and their resistance to pathogens (Tarić et al., 2019).

The results of all mentioned published studies are summarized in Table 1. With the exception of the first studies done by Kulinčević et al. (1990) applying serological test and the studies performed by Milićević et al. (2018) on honey samples or on small number of apiaries (4), in which some of bee viruses (CBPV and SBV or ABPV, CBPV, SBV and DWV) were not detected, in all other studies, all tested viruses (ABPV, CBPV, SBV, DWV and BQCV, except $\mathrm{CWV}$ ) were detected at a high percentage. In these studies, ABPV was present in a range from 7.14 up to $90 \%$ of samples, CBPV from 3.3 up to $100 \%$, SBV from 3.3 up to $96.67 \%$, DWV from 3.3 up to $100 \%$ and BQCV from 50 up to $100 \%$ of tested honeybee samples. CWV presence was tested in only one study (Kulinčević et al., 1990) in small number of samples and found to be present in up to $20 \%$ of the honeybee samples. Only KBV was not detected in any of tested samples and studies in Serbia (Table 1).

Table 1: Presence and prevalence of honeybee viruses (ABPV, CBPV, SBV, DWV, BQCV, KBV and CWV) in examined honeybee (and honey) samples and apiaries from different regions of the Republic of Serbia from 1986 until 2019

\begin{tabular}{lccccccccccc}
\hline & $\begin{array}{c}\text { No sam- } \\
\text { ples / } \\
\text { Livess } \\
\text { Lapiaries) }\end{array}$ & $\begin{array}{c}\text { Year of } \\
\text { testing }\end{array}$ & ABPV & CBPV & SBV & DWV & BQCV & KBV & CWV & References \\
\hline Belgrade & $5(2)$ & 1986 & 60.0 & 0 & 0 & 100 & 0 & $/$ & 20.0 & Kulinčević \\
Belgrade & $14(2)$ & 1987 & 7.14 & 0 & 0 & 0 & 50 & $/$ & 14.29 & et al., 1990 \\
\hline
\end{tabular}


Arhiv veterinarske medicine, Vol. 14, No. 2, 97 - 117, 2021

Petrović, T... et al.: Honeybee viruses...

\begin{tabular}{|c|c|c|c|c|c|c|c|c|c|c|}
\hline \multirow{2}{*}{ Location } & \multirow{2}{*}{$\begin{array}{c}\text { No sam- } \\
\text { ples / } \\
\text { hivess } \\
\text { (apiaries) }\end{array}$} & \multirow{2}{*}{$\begin{array}{l}\text { Year of } \\
\text { testing }\end{array}$} & \multicolumn{7}{|c|}{ Presence / prevalence of honeybee viruses \% } & \multirow{2}{*}{ References } \\
\hline & & & $\mathrm{ABPV}$ & СBPV & SBV & DWV & $\mathrm{BQCV}$ & $\mathrm{KBV}$ & $\mathrm{CWV}$ & \\
\hline $\begin{array}{c}\text { South Bačka } \\
\text { District }\end{array}$ & $20(9)$ & $\begin{array}{l}2011- \\
2013 \\
\end{array}$ & 50.0 & 85.0 & 80.0 & 55.0 & 100 & 0 & l & \multirow{2}{*}{$\begin{array}{l}\text { Petrović et } \\
\text { al., } 2013\end{array}$} \\
\hline Srem District & $10(6)$ & $\begin{array}{l}2011- \\
2013\end{array}$ & 70.0 & 10.0 & 40.0 & 90.0 & 100 & 0 & l & \\
\hline $\begin{array}{l}\text { Vojvodina } \\
\text { province - } \\
\text { Northern } \\
\text { Serbia }\end{array}$ & $10(2)$ & 2013 & 100 & I & l & 100 & I & l & l & \multirow{5}{*}{$\begin{array}{l}\text { Simeunović } \\
\text { et al., } 2014\end{array}$} \\
\hline Western Serbia & $15(3)$ & 2013 & 46.67 & l & l & 60.0 & / & l & I & \\
\hline Central Serbia & $15(3)$ & 2013 & 26.67 & l & l & 73.33 & l & l & l & \\
\hline Eastern Serbia & $10(2)$ & 2013 & 90.0 & I & I & 80.0 & I & I & l & \\
\hline $\begin{array}{l}\text { Southern } \\
\text { Serbia }\end{array}$ & $5(1)$ & 2013 & 40.0 & I & I & 80.0 & I & I & I & \\
\hline $\begin{array}{c}\text { Central \& } \\
\text { Northern } \\
\text { Serbia -honey } \\
\text { samples }\end{array}$ & $\begin{array}{c}30^{\star *} \\
\text { honeys }\end{array}$ & $\begin{array}{c}2015- \\
2016\end{array}$ & 0 & 0 & 0 & 0 & 80.0 & 0 & I & \multirow[t]{2}{*}{$\begin{array}{c}\text { Milićević et } \\
\text { al., } 2018\end{array}$} \\
\hline Central Serbia & $40(4)$ & $\begin{array}{l}2016- \\
2017\end{array}$ & 0 & 0 & 0 & 0 & 80.0 & 0 & I & \\
\hline $\begin{array}{l}\text { Vojvodina } \\
\text { province - } \\
\text { Northern } \\
\text { Serbia }\end{array}$ & $50(10)^{\star}$ & 2017 & 68.2 & 0 & 54.5 & 70.5 & I & l & I & \multirow{5}{*}{$\begin{array}{c}\text { Ćirković et } \\
\text { al., } 2018\end{array}$} \\
\hline Western Serbia & $30(6)^{*}$ & 2017 & 46.7 & 23.3 & 6.7 & 66.7 & 1 & I & I & \\
\hline Central Serbia & $30(6)^{*}$ & 2017 & 16.7 & 3.3 & 3.3 & 83.3 & I & I & I & \\
\hline Eastern Serbia & $25(5)^{*}$ & 2017 & 56.0 & 12.0 & 4.0 & 80.0 & I & I & I & \\
\hline $\begin{array}{l}\text { Southern } \\
\text { Serbia }\end{array}$ & $25(5)^{\star}$ & 2017 & 52.4 & 19.0 & 14.3 & 71.4 & I & I & I & \\
\hline $\begin{array}{l}\text { Pešter Plateau, } \\
\text { Raška District } \\
\text { (commer- } \\
\text { cial hives) }\end{array}$ & $120(15)$ & 2017 & 83.33 & 100 & 96.67 & 100 & I & l & I & \multirow{2}{*}{$\begin{array}{c}\text { Tarić et } \\
\text { al., } 2019\end{array}$} \\
\hline $\begin{array}{l}\text { Pešter Plateau, } \\
\text { Raška District } \\
\text { (trmka hives) }\end{array}$ & $24(3)$ & 2017 & 33.33 & 33.33 & 33.33 & 33.33 & I & I & I & \\
\hline
\end{tabular}




\begin{tabular}{|c|c|c|c|c|c|c|c|c|c|c|}
\hline \multirow{2}{*}{ Location } & \multirow{2}{*}{$\begin{array}{c}\text { No sam- } \\
\text { ples / } \\
\text { hivess } \\
\text { (apiaries) }\end{array}$} & \multirow{2}{*}{$\begin{array}{l}\text { Year of } \\
\text { testing }\end{array}$} & \multicolumn{7}{|c|}{ Presence / prevalence of honeybee viruses \% } & \multirow{2}{*}{ References } \\
\hline & & & $\mathrm{ABPV}$ & CBPV & SBV & DWV & $\mathrm{BQCV}$ & KBV & CWV & \\
\hline $\begin{array}{l}\text { Serbia } \\
\text { (different } \\
\text { regions) }\end{array}$ & 195 & 2014 & 61.54 & 60.0 & l & 84.62 & l & l & l & \multirow{5}{*}{$\begin{array}{c}\text { Stanimirović } \\
\text { et al., } 2019\end{array}$} \\
\hline $\begin{array}{l}\text { Serbia } \\
\text { (different } \\
\text { regions) }\end{array}$ & 221 & 2015 & 81.45 & 58.82 & l & 76.47 & / & l & l & \\
\hline $\begin{array}{l}\text { Serbia } \\
\text { (different } \\
\text { regions) }\end{array}$ & 200 & 2016 & 67.5 & 60,0 & l & 85.5 & l & l & l & \\
\hline $\begin{array}{l}\text { Serbia } \\
\text { (different } \\
\text { regions) }\end{array}$ & 186 & 2017 & 65.05 & 55.38 & l & 73.12 & / & 1 & 1 & \\
\hline $\begin{array}{l}\text { Serbia } \\
\text { (different } \\
\text { regions) }\end{array}$ & 218 & 2018 & 77.98 & 64.22 & I & 87.16 & I & I & I & \\
\hline
\end{tabular}

I - not done; ${ }^{\star}$ approximately 5 samples per apiary had been tested; ${ }^{*}$ honey samples from lokal markets

The results obtained in all afore mentioned studies in Serbia, revealed a quite high prevalence of the most important bee viruses on the whole territory of Serbia. The prevalence of DWV in Serbian apiaries is similar with the findings in Hungary (72\%) (Forgách et al., 2008) and Slovenia (70\%) (Toplak et al., 2012), and slightly lower than 97\%, 91\%, 97\% and 100\% found in France, Austria, England, Uruguay and Croatia, respectively (Tentcheva et al., 2004; Berènyi et al., 2006; Baker and Schroeder, 2008; Antúnez et al., 2006; Gajger et al., 2014).

The prevalence of CBPV in the Republic of Serbia obtained in the most of the studies is higher than that reported in other European and surrounding countries. CBPV was rarely detected in French (28\%), Slovenian (18\%), Croatian (10\%), Austrian (9\%), Danish (4\%) and Turkish (1.8\%) surveys (Tentcheva et al., 2004; Toplak et al., 2012; Gajger et al., 2014; Berènyi et al., 2006; Nielsen et al., 2008; Cagirgan and Yazici, 2021). However, the obtained prevalence of ABPV in Serbian apiaries (57\%) is similar to the results reported in Slovenia (40\%), Hungary (37\%), France (58\%) and Austria (68\%) (Toplak et al., 2012; Forgách et al., 2008; Tentcheva et al., 2004; Berènyi et al., 2006), but higher than those reported in Croatia (10\%), Denmark (11\%) and Turkey (3.6\%) (Gajger et al., 2014; Nielsen et al., 2008; Cagirgan and Yazici, 2021). 
BQCV was reported as highly prevalent in studies that tested the presence of this virus in the Republic of Serbia. This virus infection has been reported to have a variable prevalence in different countries, with $1,10,18,20,30,54,83$, 86 and 90\% detection rates in Denmark, Spain, Turkey, Croatia, Hungary, Slovenia, France, Austria and Uruguay, respectively (Nielsen et al., 2008; Antúnez et al., 2012; Cagirgan and Yazici, 2021; Gajger et al., 2014; Berènyi et al., 2006; Forgách et al., 2008; Toplak et al., 2012; Tentcheva et al., 2004; Antúnez et al., 2006).

SBV was found as highly prevalent in apiaries in Vojvodina Province and in Raška District (Pešter Plateau) similarly to the results reported in Denmark, France, Croatia, Austria and Uruguay, where SBV was identified in $81,86,70$, 48 and $100 \%$ samples, respectively (Nielsen et al., 2008, Tentcheva et al., 2004; Gajger et al., 2014; Berènyi et al., 2006; Antúnez et al., 2006). However, these values were much lower in central, eastern and south-eastern parts of Serbia similarly to the results obtained in Spain (1.1\%), England (1.4\%), Hungary (2\%), Slovenia (8.3\%), and Turkey (2.7\%) (Antúnez et al., 2012; Baker and Schroeder, 2008; Forgách et al., 2008; Toplak et al., 2012; Cagirgan and Yazici, 2021).

In studies outside of Europe, that is, in different regions of China, in a study conducted in the period 2011 - 2012, BQCV was reported the prevalent virus ( $90-100 \%$ ), followed by DWV detected in $40-100 \%$, SBV in $0-100 \%$ and IAPV found in $0-60 \%$ of honeybee samples. CBPV and ABPV were detected only sporadically, and KBV was not detected at all (Ding et al., 2016). In different regions of Argentina, in a study conducted in the same period, DWV was found to be most prevalent ranging from 9 to $90 \%$, followed by BQCV found sporadically in up to $60 \%$ of the honeybee samples. ABPV and CBPV were found only sporadically $0-40 \%$, and SBV, KBV and IAPV were not detected at all (Ding et al., 2016).

\section{CONCLUSION}

The presence of bee viruses has been studied in the Republic of Serbia for more than 35 years, yet there are only a few studies performed and published mainly in the past 5 to 10 years. High prevalence of different bee viruses identified in Serbian apiaries in most of the studies may be partly explained by high density of bee colonies in geographic regions from which bee samples were collected. Also, the intensive and uncontrolled trade and transport of bee colonies, queens, or equipment could be one of the reasons for the transmission and spread of these viruses between apiaries. The tradition of beekeeping and intensive beekeeping practice in Serbia, as well as many different challenges 
influencing the health of bee colonies impose the need for more comprehensive and continuous studies on virus presence and influence on bee health. Viruses, already present in apiaries in the Republic of Serbia, in different aspects of decreased immunity in bees, could become the ultimate extinction factors for bee colonies. The knowledge on virus's presence and prevalence in apiaries will influence the existing trading practices and better protection of healthy apiaries, and improve the management of infected apiaries in the Republic of Serbia.

\section{ACKNOWLEDGEMENT}

This study was funded by Ministry of Education, Science and Technological Development of Republic of Serbia by the Contract of implementation and funding of research work of NIV-NS in 2021, Contract No: 451-03-9/202114/200031 and was also supported by Provincial Secretariat for Agriculture, Water Management and Forestry of Vojvodina, Contract No: 104-4014672/2021/01.

\section{Author's Contribution:}

TP - write the first draft of the manuscript and made substantial contributions to the basic idea, DV - contributions to the basic idea, DL and GL - were involved in drafting of the manuscript, DV and SL - critical revision of the manuscript.

\section{Competing interest}

The authors declare that they have no competing interests.

\section{REFERENCES}

1. Allen M.F. and Ball B.V. 1996. The incidence and world distribution of the honey bee viruses. Bee World, 77, 141-162. doi: 10.1080/0005772X.1996.11099306.

2. Anderson D.L. and Gibbs A.J. 1988. Inapparent virus infections and their interactions in pupae of the honey bee (Apis mellifera L) in Australia. Journal of General Virology, 69, 1617-1625. doi: 10.1099/0022-1317-697-1617.

3. Antúnez K., D’alessandro B., Corbella E., Ramallo G., Zunino P. 2006. Honeybee viruses in Uruguay. Journal of Invertebral Pathology, 93, 1, 6770. doi: 10.1016/j.jip.2006.05.009. PMID: 16843485. 
4. Antúnez K., Anido M., Garrido-Bailón E., Botías C., Zunino P., MartínezSalvador A., Martín-Hernández R., Higes M. 2012. Low prevalence of honeybee viruses in Spain during 2006 and 2007. Research in Veterinary Science, 93, 1441-1445. doi: 10.1016/j.rvsc.2012.03.006.

5. Bailey L., Gibbs A.J., Woods R.D. 1963. Two viruses from adult honeybees (Apis mellifera Linnaeus). Virology, 21, 390-395. doi: 10.1016/00426822(63)90200-9. PMID: 14081363.

6. Bailey L. and Ball B.V. 1991. Honeybee pathology, Academic Press, London, UK. eBook ISBN: 9781483288093.

7. Baker A. and Schroeder D. 2008. Occurrence and genetic analysis of picorna-like viruses infecting worker bees of Apis mellifera L. populations in Devon South West England. Journal of Invertebrate Pathology, 98,2, 239242. doi: 10.1016/j.jip.2008.02.010. PMID: 18359042.

8. Bakonyi T., Farkas R., Szendroi A., Dobos-Kovacs M., Rusvai M. 2002. Detection of acute bee paralysis virus by RT-PCR in honey bee and Varoa destructor field samples: rapid screening of representative Hungarian apiaries. Apidologie, 33, 63-74. doi: 10.1051/apido:2001004.

9. Beaurepaire A., Piot N., Doublet V., Antúnez K., Campbell E., Chantawannakul P., Chejanovsky N., Gajda A., Heerman M., Panziera D., Smagghe G., Yañez O., de Miranda J.R., Dalmon A. 2020. Diversity and Global Distribution of Viruses of the Western Honey Bee, Apis mellifera. Insects, 11, 4, 239. doi: 10.3390/insects11040239.

10. Berènyi O., Bakonyi T., Derakhshifar I., Köglberger H., Nowotny N. 2006. Occurrence of six honeybee viruses in diseased Austrian apiaries. Applied and Environmental Microbiology, 72, 2414-2420. doi: 10.1128/ AEM.72.4.2414-2420.2006. PMID: 16597939; PMCID: PMC1449027.

11. Breeze T.D., Vaissière B.E., Bommarco R., Petanidou T., Seraphides N., Kozák L., Scheper J., Biesmeijer J.C., Kleijn D., Gyldenkærne S., Moretti M., Holzschuh A., Steffan-Dewenter I., Stout J.C., Pärtel M., Zobel M., Potts S.G. 2014. Agricultural policies exacerbate honeybee pollination service supply-demand mismatches across Europe. PLoS ONE, 9, 1, e82996. doi: 10.1371/journal.pone.0082996. PMID: 24421873; PMCID: PMC3885438.

12. Cagirgan A.A. and Yazici Z. 2021. The prevalence of seven crucial honeybee viruses using multiplex RT-PCR and their phylogenetic analysis. Turkish Journal of Veterinary \& Animal Sciences, 45, 44-55. doi: 10.3906/vet2004-139.

13. Chagas D.B., Monteiro F.L., Hübner S.d.O., Lima M.D., Fischer G. 2019. Viruses that affect Apis mellifera and their occurrence in Brazil. Ciência Rural, 49, 9, e20181042. doi: 10.1590/0103-8478cr20181042. 
14. Chapman N.C., Sheng J., Lim J., Malfroy S.F., Harpur B.A., Zayed A., Allsopp M.H., Rinderer T.E., Roberts J.M.K., Remnant E.J., Oldroyd B.P. 2019. Genetic origins of honey bees (Apis mellifera) on Kangaroo Island and Norfolk Island (Australia) and the Kingdom of Tonga. Apidologie, 50, 28-39. doi: 10.1007/s13592-018-0615-x.

15. Chen Y., Zhao Y., Hammond J., Hsu H., Evans J., Feldlaufer M. 2004. Multiple virus infections in the honey bee and genome divergence of honey bee viruses. Journal of Invertebrate Pathology, 87, 2-3, 84-93. doi: 10.1016/j. jip.2004.07.005. PMID: 15579317.

16. Chen Y.P. and Siede R. 2007. Honey bee viruses. Advances in Virus Research, 70, 33-80. doi: 10.1016/S0065-3527(07)70002-7. PMID: 17765703

17. Ćirković D., Stevanović J., Glavinić U., Aleksić N., Djurić S., Aleksić J., Stanimirović Z. 2018. Honey bee viruses in Serbian colonies of different strength. PeerJ, 6, e5887. doi: 10.7717/peerj.5887. PMID: 30479890; PMCID: PMC6240340.

18. de Miranda J., Cordoni G., Budge G. 2010. The Acute bee paralysis virus-Kashmir bee virus-Israeli acute paralysis virus complex. Journal of Invertebral Pathology, 103, Suppl 1, S30-47. doi: 10.1016/j.jip.2009.06.014. PMID: 19909972.

19. de Miranda J. and Genersch E. 2010. Deformed wing virus. Journal of Invertebral Pathology, 103, Suppl 1, S48-61. doi: 10.1016/j.jip.2009.06.012.

20. de Miranda J., Gauthier L., Ribiere M., Chen Y. 2012. Honey bee viruses and their effect on bee and colony health. In Honey bee colony health: Challenges and sustainable solutions, Ed. Diana Sammataro and Jay A. Yoder, CRC Press, Taylor and Francis eBook, ISBN 9780429185045 pp. 71102. doi: $10.1201 / \mathrm{b} 11318$

21. Ding G., Fondevila N., Palacio M.A., Merke J., Martinez A., Camacho B., Aignasse A., Figini E., Rodriguez G., Lv L., Liu Z., Shi W. 2016. Prevalence of honeybee viruses in different regions of China and Argentina. Rev Sci Tech, 35,3, 825-833. doi: 10.20506/rst.35.3.2572. PMID: 28332647.

22. Forgách P., Bakonyi T., Tapaszti S., Nowotny N., Rusvai M. 2008. Prevalence of pathogenic bee viruses in Hungarian apiaries: situation before joining the European Union. Journal of Invertebrate Pathology, 98, 235-238. doi: 10.1016/j.jip.2007.11.002. PMID: 18155230.

23. Francis R.M., Nielsen S.L., Kryger, P. 2013. Varroa-virus interaction in collapsing honey bee colonies. PLoS ONE, 8, 3, e57540. doi: 10.1371/journal. pone.0057540. PMID: 23526946; PMCID: PMC3602523

24. Gajger I.T., Bičak J., Belužić R. 2014. The occurrence of honeybee viruses in apiaries in the Koprivnica-Križevci district in Croatia. Veterinarski arhiv, 84, 4, 421-428. 
25. Grozinger C.M. and Flenniken M.L. 2019. Bee Viruses: Ecology, Pathogenicity, and Impacts. Annual Review of Entomology, 64, 205-226. doi: 10.1146/annurev-ento-011118-111942. PMID: 30629896.

26. Kulinčević J., Ball B., Mladjan V. 1990. Viruses in honey bee colonies infested with Varroa jacobsoni: first findings in Yugoslavia. Acta Veterinaria Beograd, 40, 37-42.

27. Levin S., Sela N., Erez T., Nestel D., Pettis J., Neumann P., Chejanovsky N. 2019. New Viruses from the Ectoparasite Mite Varroa destructor Infesting Apis mellifera and Apis cerana. Viruses, 11, 2, 94. doi: 10.3390/v11020094.

28. McMenamin A.J. and Flenniken M.L. 2018. Recently identified bee viruses and their impact on bee pollinators. Current Opinion in Insect Science, 26, 120-129. doi: 10.1016/j.cois.2018.02.009. Epub 2018 Feb 13. PMID: 29764651

29. Milićević V., Radojičić S., Kureljušić J., Šekler M., Nešić K., Veljović L., Maksimović Zorić J., Radosavljević V. 2018. Molecular detection of black queen cell virus and Kashmir bee virus in honey. AMB Express, 8, 1, 128. doi: 10.1186/s13568-018-0655-7. PMID: 30088183; PMCID: PMC6081484

30. Morse R.A. and Calderone N.W. 2000. The value of honey bee pollination the United States. Bee Culture, 128, 1-15.

31. Nielsen S.L., Nicolaisen M., Kryger, P. 2008. Incidence of acute bee paralysis virus, black queen cell virus, chronic bee paralysis virus, deformed wing virus, Kashmir bee virus and sacbrood virus in honey bees (Apis mellifera) in Denmark. Apidologie, 39, 310-314. doi: 10.1051/apido:2008007.

32. O'Neal T.S., Anderson T.D., Wu-Smart J.Y. 2018. Interactions between pesticides and pathogen susceptibility in honey bees. Current Opinion Insect Science, 26, 57-62. doi: 10.1016/j.cois.2018.01.006. PMID: 29764661.

33. Petrović T., Vidanović D., Stojanov I., Lupulović D., Lazić G., Plavsa N., Lazić S. 2013. First molecular detection of six honeybee viruses in Serbian apiaries. In Proceedings of the 10th International Symposium Modern Trends in Livestock Production, Belgrade, Serbia, October 2-4, 2013, 627-637.

34. Simeunović P., Stevanović J., Vidanović D., Nišavić J., Radović D., Stanišić LJ., Stanimirović Z. 2014. A survey of deformed wing virus and acute bee paralysis virus in honey bee colonies from Serbia using real-time RT-PCR. Acta Veterinaria-Beograd, 64, 81-92. doi: 10.2478/acve-2014-0009.

35. Stanimirović Z., Glavinić U., Ristanić M., Aleksić N., Jovanović N., Vejnović B., Stevanović J. 2019. Looking for the causes of and solutions to the issue of honey bee colony losses. Acta Veterinaria-Beograd, 69, 1, 1-31. doi: 10.2478/acve-2019-0001. 
36. Tantillo G., Bottaro M., Di Pinto A., Martella V., Di Pinto P., Terio V. 2015. Virus infections of honeybees Apis Mellifera. Italian journal of food safety, 4, 3, 5364. doi: 10.4081/ijfs.2015.5364. PMID: 27800411; PMCID: PMC5076640.

37. Tarić E., Glavinić U., Stevanović J., Vejnović B., Aleksić N., Dimitrijevic V., Stanimirovic Z. 2019. Occurrence of honey bee (Apis mellifera L.) pathogens in commercial and traditional hives. Journal of Apicultural Research, 58, 3, 433-443. doi: 10.1080/00218839.2018.1554231.

38. Tentcheva D., Gauthier L., Zappulla N., Dainat B., Cousserans F., Colin M.E., Bergoin M. 2004. Prevalence and seasonal variations of six bee viruses in Apis mellifera L. and Varroa destructor mite populations in France. Applied and Environmental Microbiology, 70, 12, 7185-7191. doi: 10.1128/ AEM.70.12.7185-7191.2004. PMID: 15574916; PMCID: PMC535170.

39. Toplak I., Rihtarič D., Ciglenečki U.J., Hostnik P., Jenčič V., Barlič-Maganja D. 2012. Detection of six honeybee viruses in clinically affected colonies of Carniolan gray bee (Apis mellifera carnica). Slovenian Veterinary Research, 49, 89-96.

40. Ullah A., Tlak Gajger I., Majoros A., Dar S.A., Khan S., Kalimullah Haleem Shah A., Nasir Khabir M., Hussain R., Khan H.U., Hameed M., Anjum S.I. 2021. Viral impacts on honey bee populations: A review. Saudi journal of biological sciences, 28, 1, 523-530. doi: 10.1016/j.sjbs.2020.10.037. PMID: 33424335; PMCID: PMC7783639.

41. White G.F. 1913. Sacbrood, a disease of bees. US Department of Agriculture, Bureau of Entomology, Washington, DC, USA.

Received: 12.12.2021.

Accepted: 29.12.2021. 